\title{
Altered expression of glucose transporter isoforms with aging in rats - selective decrease in GluT4 in the fat tissue and skeletal muscle
}

\author{
J.-L. Lin, T. Asano, Y.Shibasaki, K. Tsukuda, H. Katagiri, H. Ishihara, F. Takaku and Y. Oka \\ Third Department of Internal Medicine, Faculty of Medicine, University of Tokyo, Tokyo, Japan
}

\begin{abstract}
Summary. To elucidate the cellular mechanisms of glucose intolerance associated with aging, both the protein and mRNA levels of glucose transporter isoforms were studied in the various tissues of young ( 7 -week-old) and aged (20-monthold) rats. GluT4 (adipose/muscle-type glucose transporter) protein, which is specifically expressed in insulin-responsive tissues, was selectively decreased per milligramme of cellular membrane protein in both the epididymal fat tissues and the gastrocnemius muscle of the aged rats compared with the young rats. When the changes in total cellular membranes per gramme of tissue are taken into account, a further decrease in GluT4 protein per gramme of tissue was observed in the tissues of the aged rats compared with the young rats. The decreased amount of GluT4 protein in the fat tissues of the aged rats is probably due to the decreased protein synthesis rather than the stability, since GluT4 mRNA $/ \mu \mathrm{g}$ of cellular total RNA was also decreased. In contrast, GluT4 mRNA in
\end{abstract}

the gastrocnemius muscle was rather increased and a ratio of GluT4 protein/GluT4 mRNA was decreased by $70 \%$ in the aged rats, suggesting that the translational efficiency and/or stability of GluT4 protein is decreased in the skeletal muscle of the aged rats compared with the young rats. GluT2 (livertype glucose transporter) protein and mRNA in the liver were also decreased in the aged rats, while no apparent decrease in GluT1 (HepG2/brain-type glucose transporter) protein/mg of cellular membrane protein was observed in the skeletal muscle and fat tissues of the aged rats compared with the young rats. Thus, the tissue and isoform-specific alterations of glucose transporter expression are associated with aging and may contribute to glucose intolerance observed with aging.

Key words: Glucose transporter, glucose transporter mRNA, aging.
Impaired glucose tolerance has long been known to accompany aging [1-3]. However, relatively little is known about its mechanisms. Conflicting results have been reported on the changes of insulin binding during aging [26] and several studies have demonstrated that this age-related carbohydrate intolerance is due, at least in part, to a post-receptor defect in insulin-mediated peripheral glucose uptake [2-7]. In addition, a decrease in inhibition of hepatic glucose output by physiological concentrations of insulin with age has also been reported $[1,2,8]$.

Glucose transport across the plasma membrane is mediated by carrier proteins termed glucose transporters $[9,10]$. Recent cDNA cloning has demonstrated that the facilitative glucose transporters comprise a family of structurally related proteins with different tissue distributions [11-20]. We have studied the GluT1 glucose transporter mRNA in various tissues of fetal and adult rats and have demonstrated that significant changes in glucose transporter expression occurred during the developing period [21]. Glucose transporter expression is also altered in many physiological and pathological conditions such as diabetes mellitus [22-24], which contributes to the insulin resistance observed in this disease. These results suggest that quantitative and/or qualitative changes of the expression of glucose transporter isoforms may play an important role in age-related impaired glucose tolerance. In an effort to further elucidate the mechanisms of glucose intolerance in aging, we have investigated the age-related changes of the protein and $\mathrm{mRNA}$ levels of glucose transporter isoforms in the rat skeletal muscle, fat tissue and liver.

\section{Materials and methods}

\section{Animals}

Seven-week and 20-month-old male rats of Wistar strain (Nisseizai, Tokyo, Japan) were used as the young and the aged rats, respectively. The animals were fed ad libitum and killed between 10.00 and 11.00 hours without overnight fast. Basically, three rats were used for each group and termed A, B, C in the young rats and D, E, F in 
the aged rats. However, because the RNA of the skeletal muscle was found to be degraded during the preparation, another set of three young rats and three aged rats were used for western and northern blotting of the skeletal muscle. In addition, there were not enough epididymal fat tissues of one young rat for both Western blotting and Northern blotting. Therefore, 12 young rats were used for preparing total RNA for three groups (four rats for one group) of the young rats. Thus, the young rats used for northern blotting of the fat tissues and the rats used for the study of the skeletal muscle were neither rat $\mathrm{A}, \mathrm{B}, \mathrm{C}$ nor rat $\mathrm{D}, \mathrm{E}, \mathrm{F}$.

\section{Preparation of membranes}

Total membrane particulate fractions from rat tissues were prepared as previously described with some modifications [25]. Rat epididymal fat tissues and the entire gastrocnemius muscle were excised and homogenized by Polytron (Kinematica, Littau, Switzerland) in $10 \mathrm{mmol} / \mathrm{l} \mathrm{Tris-HCl}, 1 \mathrm{mmol} / \mathrm{l}$ EDTA, $250 \mathrm{mmol} / 1$ sucrose, $\mathrm{pH} 7.4$, containing $1 \mathrm{mmol} / \mathrm{l}$ phenylmethyl sulphonyl fluoride. The homogenates were centrifuged at $900 \times g$ for $10 \mathrm{~min}$ at $4^{\circ} \mathrm{C}$ to sediment the fraction containing mainly the nuclei and mitochondria. The resulting supernatant was centrifuged at $146,000 \times g$ for $75 \mathrm{~min}$ at $4^{\circ} \mathrm{C}$ to yield a pellet designated as the total membrane fraction in this study. To prepare the total membrane particulate fractions from the livers, rat livers were excised and 3-6 g of each liver slice was homogenized by a Potter-Elvehjem glass-Teflon homogenizer in $25 \mathrm{ml}$ of $10 \mathrm{mmol} / 1$ Tris-HCl, $1 \mathrm{mmol} / 1$ EDTA, $250 \mathrm{mmol} / \mathrm{l}$ sucrose, $\mathrm{pH} 7.4$, containing $1 \mathrm{mmol} / \mathrm{l}$ phenylmethyl sulphonyl fluoride and 1000 units $/ \mathrm{ml}$ of aprotinin. The homogenates were centrifuged at $700 \times g$ for $10 \mathrm{~min}$ at $4^{\circ} \mathrm{C}$ to sediment the fraction containing mainly the nuclei and mitochondria. The resulting supernatant was centrifuged at $146,000 \times g$ for $75 \mathrm{~min}$ at $4^{\circ} \mathrm{C}$ to yield a pellet designated as the total membrane fraction of the liver in this study.

\section{Western blot analysis}

Production and characterization of antibodies raised against synthetic peptides corresponding to the $\mathrm{COOH}$-terminal domain of the rat Glu'T1 glucose transporter (residues 478-492), rat GluT2 glucose transporter (residues 508-522) and rat GluT4 (residues 495-509) have been previously described $[25,26]$. Membrane fractions $(0.1 \mathrm{mg})$ prepared as described above were suspended in $1 \%$ sodium dodecyl sulphate (SDS) and $50 \mathrm{mmol} / \mathrm{l}$ dithiothreitol and subjected to SDS-polyacrylamide (10\%) gel electrophoresis as described by Laemmli [27]. Electrophoretic transfer to nitrocellulose paper and detection of the immunocomplex with ${ }^{125}$ I-labelled protein $\mathrm{A}$ (Amersham Co, Amersham, Buckinghamshire, UK) were carried out as described previously [28] using antisera at a final dilution of 1:40. The dried blots were autoradiographed using Fuji RX x-ray film and intensifying screen at $-70^{\circ} \mathrm{C}$. Prestained molecular weight standard (Bio-Rad, Richmond, Va, USA) was used for estimation of the molecular weight. The experiments were performed at least twice for each tissue with similar results.

Table 1. Characteristics of the experimental rats

\begin{tabular}{lllll}
\hline & $\begin{array}{l}\text { Young } \\
(\mathrm{A}, \mathrm{B}, \mathrm{C})\end{array}$ & $\begin{array}{l}\text { Aged } \\
(\mathrm{D}, \mathrm{E}, \mathrm{F})\end{array}$ & Young $^{\mathrm{a}}$ & Aged $^{\mathrm{a}}$ \\
\hline Body weight (g) & $196 \pm 8$ & $570 \pm 60$ & $207 \pm 7$ & $627 \pm 31$ \\
$\begin{array}{l}\text { Fat tissue weight (g) } \\
0.91 \pm 0.11\end{array}$ & $11.7 \pm 1.4$ & & \\
$\begin{array}{l}\text { Liver weight (g) } \\
\text { Gastrocnemius }\end{array}$ & $10.6 \pm 1.2$ & $30.2 \pm 4.6$ & & \\
$\begin{array}{l}\text { weight (g) } \\
\begin{array}{l}\text { Plasma glucose } \\
\text { (mmol/l) }\end{array}\end{array}$ & $2.25 \pm 0.09$ & $7.10 \pm 0.58$ & $2.36 \pm 0.05$ & $6.95 \pm 0.44$ \\
\hline
\end{tabular}

${ }^{a}$ Rats used for the studies on gastrocnemius
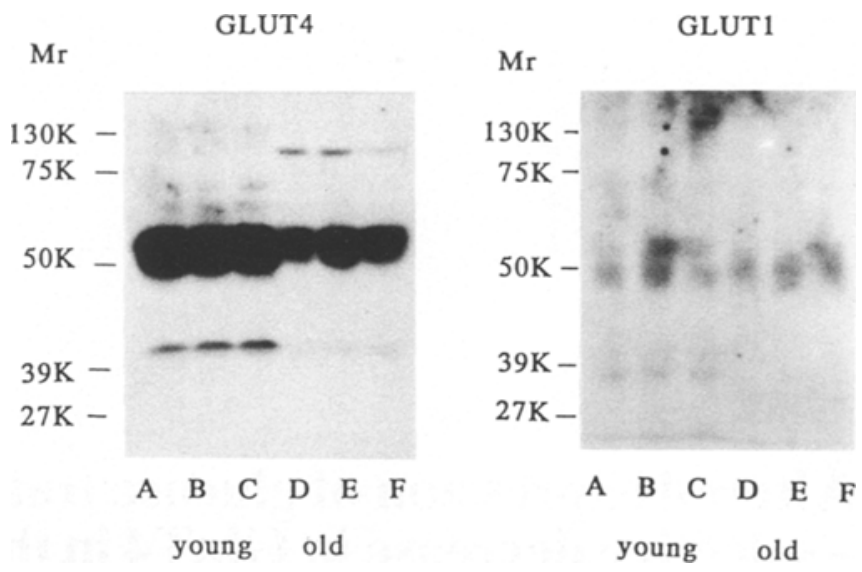

Fig. 1. Western blot analysis of the total membranes from epididymal fat tissues of young (A, B, C) and aged rats (D, E, F). Western blot analysis of total membranes $(100 \mu \mathrm{g})$ was performed with antipeptide antibody directed against the COOH-terminal domain of rat GluT4 glucose transporter (left) or rat GluT1 glucose transporter (right)

\section{Northern blot analysis}

Cellular total RNA was prepared from rat tissues by the lithium/urea procedure as described previously [21]. RNA $(20 \mu \mathrm{g})$ was denatured with formaldehyde, separated by $1.2 \%$ agarose gel electrophoresis [29], and transferred onto a nitrocellulose filter (Schleicher and Schuell, Dassel, FRG). The cDNA for glucose transporter isoforms were prepared as previously described $[21,26]$ and the MaeI fragment of rabbit GluT1 cDNA (nucleotide 111-2230), EcoRI fragment of mouse GluT2 cDNA (nucleotide 1-1552), and DraI-XbaI fragment of rat GluT4cDNA (nucleotide 143-1947) were labelled with ${ }^{32}$ Phosphate by random priming and used for the measurement of rat GluT1, GluT2 and GluT4 mRNA, respectively. Hybridization of the filters with the probes was carried out in $50 \%$ formamide, $5 \times \mathrm{SSC}(1 \times \mathrm{SSC}=150 \mathrm{mmol} / 1 \mathrm{NaCl}, 15 \mathrm{mmol} / \mathrm{lsodium}$ citrate), $5 \times$ Denhardt's solution $(1 \times$ Denhardt's solution $=0.02 \%$ polyvinyl pyrrolidone, $0.02 \%$ Ficoll, $0.02 \%$ bovine serum albumin), $50 \mathrm{mmol} / \mathrm{l}$ sodium phosphate buffer, ph $7.0,1 \%$ SDS at $42^{\circ} \mathrm{C}$. The filters were washed with $0.2 \%$ SDS, $0.5 \times \mathrm{SSC}$ at $42^{\circ} \mathrm{C}$ for $30 \mathrm{~min}$ and subjected to autoradiography. The experiments were carried out at least twice for each tissue with similar results being obtained.

\section{Results}

The characteristics of the experimental animals are shown in Table 1. The weight of fat tissues was markedly increased in the aged rats compared with the young rats. The weight of gastrocnemius and liver was also increased in the aged rats compared with the young rats. Plasma glucose levels were not significantly different between the young and the aged rats.

\section{Fat tissues}

Since rat fat tissue contains two glucose transporter isoforms, GluT1 and GluT4 [25, 30], Western blotting was performed for these two glucose transporter isoforms. The antibody raised against the $\mathrm{COOH}$-terminal domain of GluT4 glucose transporter recognized a $50,000-\mathrm{M}_{\mathrm{r}}$ protein (Fig.1, left panel). The size of this protein band is similar to that reported for rat GluT4. This protein band is also observed in the low density microsomes prepared from isolated adipocytes and is decreased in this mem- 


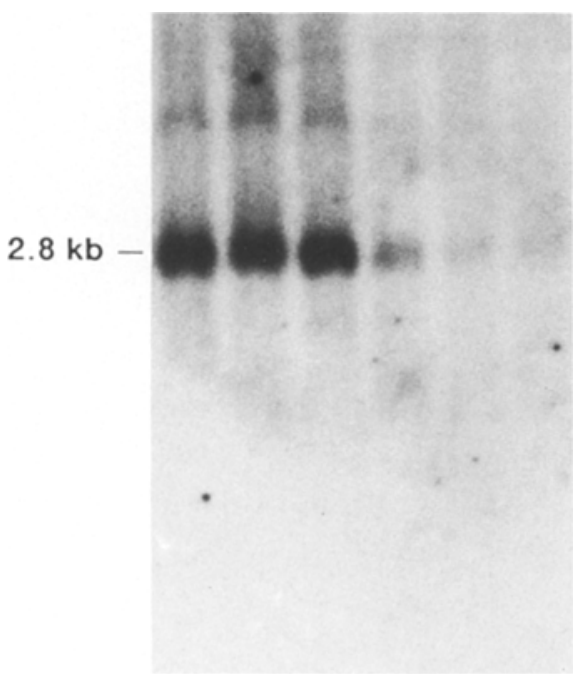

young old

Fig.2. Northern blot analysis of GluT4 mRNA in $20 \mu \mathrm{g}$ cellular RNA from fat tissues of young $(A, B, C)$ and aged rats $(D, E, F)$

brane fraction by insulin treatment of the cells (data not shown), indicating that this protein band is indeed GluT4. Interestingly, GluT4 glucose transporter in the fat tissues of aged rats is markedly decreased compared with that of young rats. Quantitation of the radioactivity in the GluT4 glucose transporter band isolated from the nitrocellulose paper revealed that the amount of GluT4 per mg of cellular membrane protein was decreased by $58 \%$ in the fat tissues of the aged rats compared with that observed in the young rats. Although the total cellular membrane protein per one epididymal fat pad was greater ( 4.4 fold) in the aged rats compared with the young rats, the amount of GluT4 per one epididymal fat pad was increased a little less than two-fold in the aged rats compared with the young rats. Quite different results were obtained on GluT1 glucose transporter (Fig.1, right panel). The amount of GluT1 glucose transporter isoform per mg of cellular membrane protein of fat tissues, which was recognized with the antibody raised against the $\mathrm{COOH}$-terminal domain of the rat GluT1 glucose transporter [25], was not altered between the young and aged rats.

Because the amount of GluT4 in rat fat tissues was markedly decreased in the aged rats, we then studied the level of rat GluT4 mRNA. Rat GluT4 cDNA hybridized to 2.8 kilobases of $\mathrm{mRNA}$ from the fat tissues of the young and the aged rat under stringent hybridization conditions. This size class of mRNA was identical to that previously reported for rat GluT4 mRNA. The GluT4 mRNA per $\mu \mathrm{g}$ total RNA in the fat tissues of aged rats was decreased to $33 \%$ of that in the young rats (Fig. 2).

\section{Skeletal muscle}

The skeletal muscle plays a much more important role in glucose handling compared with the adipose tissues [31] and is likely to be more responsible for insulin resistance associated with aging. Therefore, we studied glucose transporter protein and mRNA in the gastrocnemius muscle of the young and the aged rats. As shown in Figure 3 , the $M_{r} 50,000$ protein was recognized with the antibody against $\mathrm{COOH}$-terminal domain of GluT4 glucose transporter in the muscle of both young and aged rats. This protein was also recognized in the low density microsomal fraction of rat adipocytes (lane 7). The membranes obtained from the gastrocnemius, which derived from a mixture of cell types, contained a considerable amount of GluT4, considering that the muscle membranes used were crude and that the low density microsome of adipocytes was a special subcellular membrane fraction rich in glucose transporter. Quantitation of the radioactivity in GluT4 protein band revealed that the amount of GluT4 protein per unit weight of muscle membrane was significantly decreased in the aged rats compared with the young rats $(8,890 \pm 1,101 \mathrm{cpm}$ in the young rats vs $6,189 \pm$ $793 \mathrm{cpm}$ in the aged rats, $p<0.05)$. The membranes recovered from the gastrocnemius were increased two-fold in the aged rats compared with the young rats. Thus, the amount of GluT4 per one gastrocnemius muscle was increased by only $50 \%$ in the aged rats compared with the young rats, although the weight of the gastrocnemius was increased approximately three-fold in the aged rats. GluT1 glucose transporter was also present in the membranes obtained from gastrocnemius (Fig. 3, right panel). In contrast to the changes in GluT4, no apparent difference in the amount of GluT1 was observed in the gastrocnemius between the young and aged rats, similar to the results observed in the fat tissues.

GluT4 mRNA level was also determined by using rat GluT4 cDNA as a probe. Surprisingly, the amount of $2.8 \mathrm{ki}-$ lobase mRNA for GluT4 per $\mu \mathrm{g}$ of cellular total RNA was rather increased in the aged rats (Fig. $4 \mathrm{~A}$ ). This is not due to the difference in the amount of applied RNA or degradation of RNA, as demonstrated by staining of the RNA in the gel with ethidium bromide (Fig. 4B). Densitometric scanning revealed that a relative density of the band for
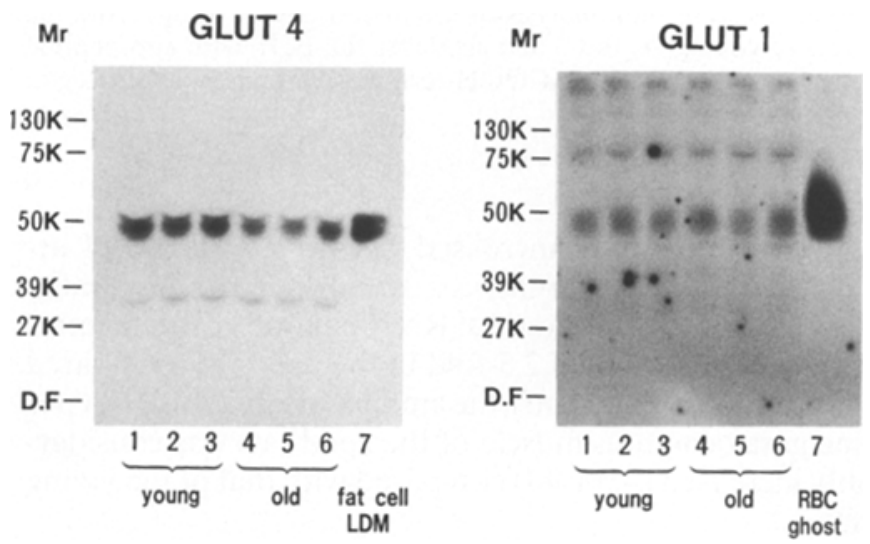

Fig. 3. Western blot analysis of the membranes (100 $\mu \mathrm{g})$ from gastrocnemius of young (lane 1-3) and aged rats (lane 4-6) with antipeptide antibody directed against the COOH-terminal domain of rat GluT4 glucose transporter (left) and rat GluT1 glucose transporter (right). $25 \mu \mathrm{g}$ low density microsomes (LDM) from rat adipocytes and $1 \mu \mathrm{g}$ human erythrocyte (RBC) membrane was shown in lane 7 of the left panel and lane 7 of the right panel, respectively, for comparison 
A

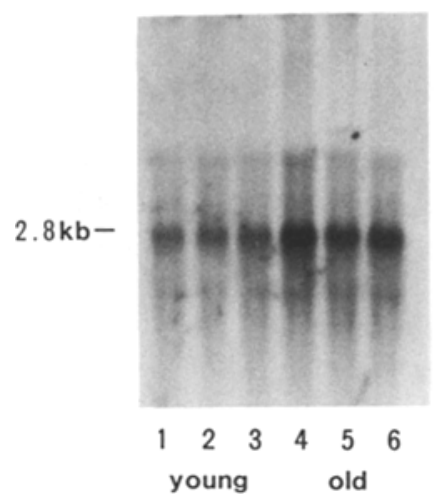

B

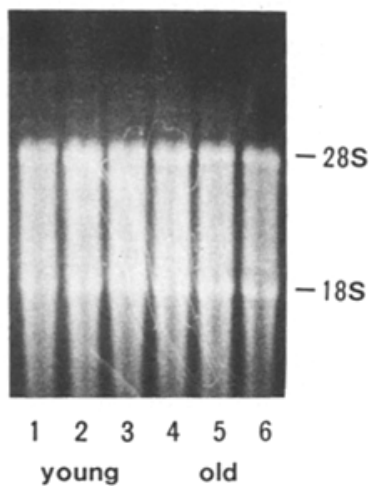

Fig. 4. A Northern blot analysis of GluT4 mRNA in $20 \mu \mathrm{g}$ cellular RNA from gastrocnemius of young (lane 1-3) and aged rats (lane 46). B Staining with ethidium bromide of RNA in the gel which was used for Northern blot analysis shown in Figure $4 \mathrm{~A}$

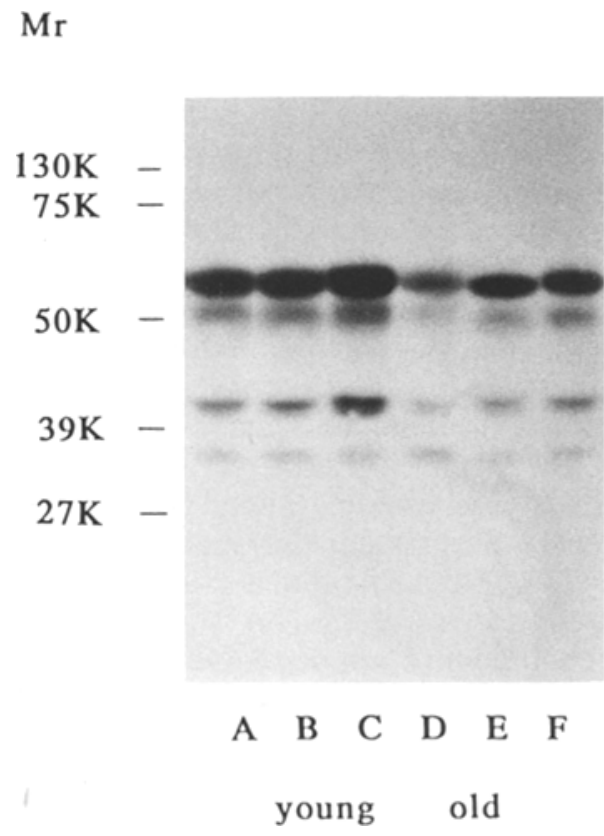

Fig. 5. Western blot analysis of the membranes $(100 \mu \mathrm{g})$ from the livers of young $(A, B, C)$ and aged rats $(D, E, F)$ with anti-peptide antibody directed against $\mathrm{COOH}$-terminal domain of rat GluT2 glucose transporter

GluT4 mRNA was increased 1.85 -fold $(1.17 \pm 0.14$ arbitrary units in the young vs $2.16 \pm 0.46$ in the aged rats). The amount of cellular total RNA per one gastrocnemius muscle was increased 2.5-fold in the aged rats compared with the young rats. Thus, the amount of GluT4 mRNA per one gastrocnemius muscle of the aged rats was considerably increased (4.6-fold) compared with that of the young rats.

\section{Liver}

We next studied the amount of GluT2 in the livers of the young and aged rats. We used the COOH-terminal specific anti-peptide antibody [26] for Western blotting. This antibody identified the major protein with apparent mole-

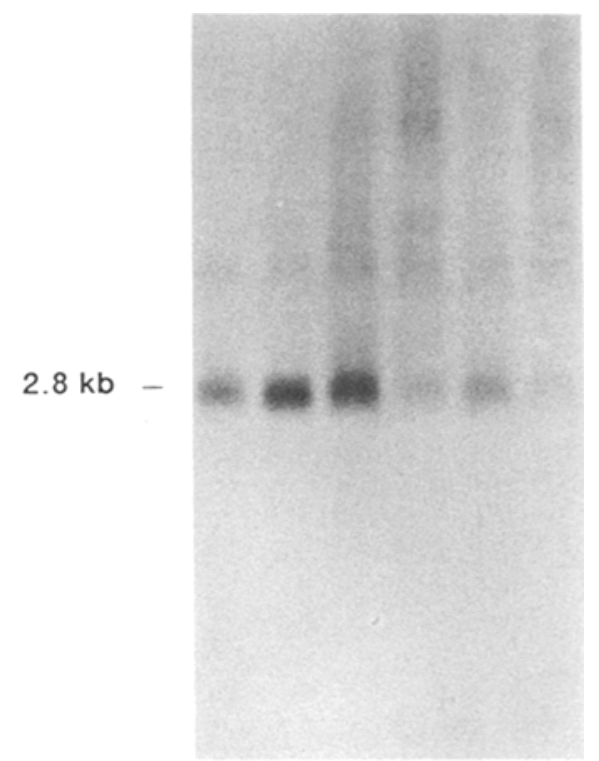

$$
\begin{array}{lllll}
\text { A } & \text { B } & \text { D } & \text { E } & \text { F } \\
\text { young } & & \text { old }
\end{array}
$$

Fig.6. Northern blot analysis of GluT2 mRNA in $20 \mu \mathrm{g}$ celiular RNA from livers of young $(A, B, C)$ and aged rats $(D, E, F)$

cular weight of 55,000 in rat liver membranes (Fig.5). Other minor protein bands, $51,000,43,000,31,000-\mathrm{M}_{\mathrm{r}}$ protein, were also recognized. These three proteins were likely to be degraded GluT2 protein, since these bands were also recognized with affinity-purified antibody [25] but not with antisera raised against the $\mathrm{COOH}$-terminal domain of rat GluT4. Quantitation of the radioactivity in the $55,000-\mathrm{M}_{\mathrm{r}}$ GluT2 glucose transporter band isolated from the nitrocellulose paper demonstrated that the amount of GluT2 in the liver from aged rats was $58 \%$ of that observed in the young rats.

The level of rat GluT2 mRNA in the livers was then studied. Fragments of mouse GluT2 cDNA [32] hybridized to 2.8 kilobases of mRNA from the livers of the young and aged rats under stringent hybridization conditions (Fig.6). This size was compatible with that previously reported for rat GluT2 mRNA [26]. The GluT2 mRNA per $\mu \mathrm{g}$ cellular RNA of the liver was markedly decreased in the aged rats compared with the young rats. Densitometric scanning of the 2.8 kilobase bands revealed that the amount of liver GluT2 mRNA in the aged rats was $53 \%$ of that in the young rats.

\section{Discussion}

The amount of GluT4 glucose transporter was markedly decreased per mg cellular membranes of the epididymal fat tissues in the aged rats, while the amount of GluT1 was not altered compared with the young rats. Thus, expression of GluT4 glucose transporter isoform was selectively decreased in rat epididymal fat pads in association with aging. These findings are interesting in that similar changes in glucose transporter isoforms are observed in 
the fat tissues from streptozotocin-induced diabetic rats which also exhibit a decrease in insulin sensitivity [22-24]. GluT4 is a dominant glucose transporter species in fat cells $[25,30]$. Furthermore, unlike GluT1 most of the GluT4 glucose transporters remain in the intracellular compartment in the basal state [30]. This means that glucose transporters which are able to be translocated to the plasma membranes upon insulin stimulation are decreased in the fat tissues in the aged rats compared with the young rats. The studies presented were performed not in isolated adipocytes but in adipose tissues also containing non-adipose cells such as connective tissue cells, which were likely to be a major source for GluT1 in the adipose tissues. It is also possible that the cell membrane protein of various cell types may chang with age. Thus, the results on GluT1 in adipose tissues may not reflect the alteration of GluT1 in isolated adipocytes. Studies in isolated adipocytes are also needed to determine whether or not the decreased stimulation of glucose transport by insulin in adipocytes of the aged rats [33] is at least partly due to the decreased number of GluT4 glucose transporters per adipocyte.

Although the total cellular membrane per one epididymal fat pad is increased in the aged rats compared with the young rats probably due to the larger tissue of the aged rats, the amount of GluT4 per one epididymal fat pad was increased approximately only two-fold in the aged compared with the young rats. This two-fold increase does not match with the increase in the body weight (approximately three-fold) observed in the aged rats. This consideration is necessary because insulin resistance in the aged rats was characterized by a decreased disposal of the glucose, which was administered on a body-weight basis [34], and decreased glucose disappearance per body weight during euglycaemic clamp [7]. However, the relative decrease in GluT4 in the fat tissues probably does not make a significant contribution to insulin resistance observed in the aged rats, since fat tissues play a relatively small role in utilizing glucose compared with skeletal muscle.

Similar changes in glucose transporter were observed also in the skeletal muscle, gastrocnemius. GluT4 but not GluT1 was selectively decreased per mg of cellular membrane of gastrocnemius in the aged rats compared with the young rats (Fig.3). Similar to the case of adipocytes, glucose transporter resides both on the cell surface and in the intracellular pool in the skeletal muscle and insulin causes a recruitment of glucose transporter from intracellular pool to the cell surface [35], which appears to be partly responsible for the increased glucose uptake induced by insulin. If one can assume that a relative distribution of glucose transporter between the cell surface and intracellular compartment in the muscle does not change with aging in the basal state, the decrease in GluT4 but not in GluT1 in the muscle of the aged rats might be responsible for the decreased basal glucose uptake in the skeletal muscle of the aged rats compared with the young rats $[34,36]$. Significantly, fewer glucose transporters available for translocation to the plasma membrane are likely to be responsible for a decrease in maximal insulin-stimulated glucose uptake in the muscle of the aged rats compared with the young rats $[34,36]$.
Skeletal muscle is the main tissue responsible for insulin-induced glucose disposal in vivo and glucose transport is known to be a rate-limiting step for glucose utilization in the skeletal muscle. Therefore, glucose transporter which catalyses glucose transport across the plasma membrane of the muscle plays an important role in regulation of plasma glucose levels. In this context it is very interesting that GluT4 in the gastrocnemius was relatively decreased (approximately 50\%) in the aged rats, i.e. the amount of GluT4 per one gastrocnemius muscle was increased by only $46 \%$ in the aged rats compared with the young rats, while body weight was increased three-fold. This relative decrease in GluT4 is likely to be, at least in part, responsible for insulin resistance observed in the aged rats.

In addition to the alteration of GluT4 in the fat tissues and skeletal muscle, the expression of liver-specific glucose transporter isoform, GluT2, is also decreased in the livers of the aged rats. The decreased GluT2 protein is probably due to the decreased GluT2 protein synthesis, since GluT2 mRNA is observed to be also decreased (Fig.6). However, it is difficult to interpret these results, because a functional role of GluT2 in the liver is not clear at present. The glucose uptake process across the hepatic plasma membrane does not appear to be rate-limiting for glucose metabolism in the liver or to be regulated by insulin $[37,38]$. Therefore, it does not appear to be likely that the decreased amount of GluT2 in the liver contributes to the decreased glucose disposal after glucose load in the aged rats. We previously reported that GluT2 in the liver was increased in streptozotocin-induced diabetic rats and speculated that increased GluT2 may contribute to the increased glucose output that occurs from hepatocytes during insulin deficiency [26]. It has been reported that the hepatic glucose output in the basal state is not different between young human subjects and healthy elderly human subjects $[1,2]$, although there have been conflicting results on inhibition of hepatic glucose output by insulin or by glucose ingestion in the young and the elderly $[1,2,8,39]$. A functional role of GluT2 in the liver as well as the physiological significance of the decreased GluT2 in the livers of the aged rats requires further investigation.

Although GluT4 protein in the epididymal fat tissue and gastrocnemius muscle is decreased in the aged rats, changes in mRNA levels for this isoform are different between these tissues. The GluT4 mRNA in the fat tissue is decreased per $\mu \mathrm{g}$ cellular RNA as shown in Figure 2, suggesting that the changes in protein levels are probably due to alteration in GluT4 protein synthesis rater than stability. In contrast, GluT4 mRNA in the muscle was rather increased per $\mu \mathrm{g}$ cellular total RNA. When the changes in the RNA per $g$ tissue are taken into account, the amount of GluT4 mRNA per one gastrocnemius of the aged rats were increased 4.6 -fold compared with the young rats. The GluT4 protein was increased only 1.5 -fold per one gastrocnemius. Thus, a ratio of GluT4 protein/GluT4 mRNA was decreased to approximately $30 \%$ in the aged compared with the young rats. Thus, the decreased amount of GluT4 in the skeletal muscle may be due to decreased translation of GluT4 mRNA and/or increased degradation of GluT4 protein. Although the results in this 
study might be due to differences in physical activity or tissue size between the young and the aged rats, rather than aging per se, the mechanisms for the decreased GluT4 in the muscle and fat tissues of the aged rats and the way to prevent it should be investigated in the future.

Acknowledgements. This work was supported in part by grants from the Sasakawa Foundation and the Sandoz Foundation.

\section{References}

1. DeFronzo RA (1979) Glucose intolerance and aging: evidence for tissue insensitivity to insulin. Diabetes 28: 1095-1101

2. Fink RI, Kolterman OG, Griffin J, Olefsky JM (1983) Mechanisms of insulin resistance in aging. J Clin Invest 71:1523-1535

3. Fink RI, Kolterman OG, Kao M, Olefsky MJ (1984) The role of the glucose transport system in the postreceptor defect in insulin action associated with human aging. J Clin Endocrinol Metab 58: $721-725$

4. Lonnroth P, Smith U (1986) Aging enhances the insulin resistance in obesity through both receptor and postreceptor alterations. J Clin Endocrinol Metab 62: 433-437

5. Pagano G, Cassader M, Perin-Cavallo P et al. (1984) Insulin resistance in the aged: a quantitative evaluation in in vivo insulin sensitivity and in vitro glucose transport. Metabolism 33: 976981

6. Fink RI, Wallace P, Olefsky JM (1986) Effects of aging on glucose-mediated glucose disposal and glucose transport. J Clin Invest 77: 2034-2041

7. Nishimura H, Kuzuya H, Okamoto M et al. (1988) Change of insulin action with aging in conscious rats determined by euglycemic clamp. Am J Physiol 254: E92-E98

8. Meneilly GS, Minaker KL, Elahi D, Rowe JW (1987) Insulin action in aging man: Evidence for tissue-specific differences at low physiological insulin levels. J Gerontology 42: 196-201

9. Wheeler TJ, Hinkle PC (1985) The glucose transporter of mammalian cells. Ann Rev Physiol 47: 503-517

10. Simpson IA, Cushman SW (1986) Hormonal regulation of mammalian glucose transport. Ann Rev Biochem 55: 1059-1089

11. Mueckler M, Caruso C, Baldwin SA et al. (1985) Sequence and structure of a human glucose transporter. Science 229: 941-945

12. Birnbaum MJ, Haspel HC, Rosen OM (1986) Cloning and characterization of a cDNA encoding the rat brain glucose transporter protein. Proc Natl Acad Sci USA 83: 5784-5788

13. Fukumoto H, Seino S, Inura H et al. (1988) Sequence, tissue distribution, and chromosomal localization of mRNA encoding a human glucose transporter-like protein. Proc Natl Acad Sci USA 85: $5434-5438$

14. Thorens B, Sarkar HK, Kaback HR, Lodish HF (1988) Cloning and functional expression in bacteria of a novel glucose transporter present in liver, intestine, kidney, and $B$ pancreatic islet cells. Cell 55: 281-290

15. Kayano T, Fukumoto H, Eddy RL et al. (1988) Evidence for a family of human glucose transporter-like proteins. J Biol Chem 263: $15245-15248$

16. James DE, Strube M, Mueckler M (1989) Molecular cloning and characterization of an insulin-regulatable glucose transporter. Nature 338: 83-87

17. Fukumoto H, Kayano T, Buse JB et al. (1989) Cloning and characterization of the major insulin-responsive glucose transporter expressed in human skeletal muscle and other insulin-responsive tissues. J Biol Chem 264: 7776-7779

18. Birnbaum MJ (1989) Identification of a novel gene encoding an insulin-responsive glucose transporter protein. Cell 57: 305-315

19. Charron MJ, Brosius III FC, Alper SL, Lodish HF (1989) A glucose transport protein expressed predominantly in insulin-responsive tissues. Proc Natl Acad Sci USA 86: 2535-2539

20. Kaestner KH, Christy RJ, McLenithan JC et al. (1989) Sequence, tissue distribution, and differential expression of mRNA for a putative insulin-responsive glucose transporter in mouse 3T3-L1 adipocytes. Proc Natl Acad Sci USA 86: 3150-3154

21. Asano T, Shibasaki Y, Kasuga Met al. (1988) Cloning of a rabbit brain glucose transporter cDNA and alteration of glucose transporter mRNA during tissue development. Biochem Biophys Res Commun 154:1204-1211

22. Berger J, Biswas C, Vicario PP, Strout HV, Saperstein R, Pilch PF (1989) Decreased expression of the insulin-responsive glucose transporter in diabetes and fasting. Nature 340: 70-72

23. Sivitz WI, DeSautel SL, Kayano T, Bell GI, Pessin JE (1989) Regulation of glucose transporter messenger RNA in insulindeficient states. Nature 340: 72-74

24. Garvey WT, Huecksteadt TP, Birnbaum MJ (1989) Pretranslational suppression of an insulin-responsive glucose transporter in rats with diabetes mellitus. Science 245: 60-63

25. Oka Y, Asano T, Shibasaki Y, Kasuga M, Kanazawa Y, Takaku F (1988) Studies with antipeptide antibody suggest the presence of at least two types of glucose transporter in rat brain and adipocyte. J Biol Chem 263: 13432-13439

26. Oka Y, Asano T, Shibasaki et al. (1990) Increased liver glucosetransporter protein and mRNA in streptozocin-induced diabetic rats. Diabetes 39: $441-446$

27. Laemmli UK (1970) Cleavage of structural proteins during the assembly of the head of bacteriophage T4. Nature 227: 680-685

28. Burnette WN (1981) "Western blotting": Electrophoretic transfer of proteins from sodium dodecyl sulfate-polyacrylamide gels to unmodified nitrocellulose and radiographic detection with antibody and radioiodinated protein A. Anal Biochem 112: 195203

29. Lehrach H, Diamond D, Wozney JM, Boedtker H (1977) RNA molecular weight determination by gel electrophoresis under denaturing conditions, a critical examination. Biochemistry 16 : $4743-4748$

30. James DE, Brown R, Navarro J, Pilch PF (1988) Insulin-regulatable tissues express a unique insulin-sensitive glucose transporter protein. Nature 333: 183-185

31. Bjorntorp P, Krotkieski M, Larsson B, Somlo-Szucs (1970) Effects of feeding states on lipid radioactivity in liver, muscle and adipose tissue after injection of labelled glucose in the rat. Acta Physiol Scan 80: 29-38

32. Asano T, Shibasaki Y, Lin J-L, Akanuma Y, Takaku F, Oka Y (1989) The nucleotide sequence of cDNA for a mouse liver-type glucose transporter protein. Nucleic Acids Res 17: 6386

33. Fink RI, Huecksteadt T, Karaoghlanian Z (1986) The effects of aging on glucose metabolism in adipocytes from Fisher rats. Endocrinology 118: 1139-1147

34. Narimiya M, Azhar S, Dolkas CB et al. (1984) Insulin resistance in older rats. Am J Physiol 246: E397-E404

35. Klip A, Ramlal T, Young DA, Holloszy JO (1987) Insulin-induced translocation of glucose transporter in rat hind-limb muscle. FEBS Lett 224: 224-230

36. Goodman MN, Dluz SM, McElaney MA, Belur E, Ruderman NB (1983) Glucose uptake and insulin sensitivity in rat muscle: changes during 3-96 week of age. Am J Physiol 244: E93-E100

37. Williams TF, Exton JH, Park CR, Regen DM (1968) Stereospecific transport of glucose in the perfused rat liver. Am J Physiol 215: 1200-1209

38. Bauer H, Heldt HW (1977) Transport of hexoses across the livercell membrane. Eur J Biochem 74:397-403

39. Jackson RA, Hawa MI, Roshania RD, Sim BM, DiSilvio L, Jaspan JB (1988) Influence of aging on hepatic and peripheral glucose metabolism in humans. Diabetes 36: 119-129

Received: 13 December 1990

and in revised form: 15 April 1991

\section{Dr. Y.Oka}

Third Department of Internal Medicine

Faculty of Medicine

University of Tokyo, 7-3-1, Bunkyo-ku

Tokyo 113, Japan 